\title{
Immunoglobulin G content and colostrum composition of different goat and sheep breeds in Switzerland and Germany
}

\author{
E. C. Kessler, R. M. Bruckmaier, and J. J. Gross* \\ Veterinary Physiology, Vetsuisse Faculty, University of Bern, CH-3012 Bern, Switzerland
}

\section{ABSTRACT}

Colostrum represents the sole source to acquire humoral immunity and is an important energy source for newborn lambs and goat kids. However, colostrum composition (i.e., the contents of IgG, fat, protein, and lactose) is affected by various factors such as parity and litter size and, potentially, by breed. In the present study, we examined the colostrum composition of different goat and sheep breeds raised for milk and meat production in Switzerland and Germany. Ten goat breeds (Anglo-Nubian, Appenzell, Boer, Bunte Deutsche Edelziege, Chamois-colored, Grisons Striped, Peacock, Saanen, Toggenburg, and Valais Blackneck) and 10 sheep breeds (Brown-Headed Meat, East Friesian Milk, German Blackheaded Mutton, Gray Horned Heath, Lacaune Dairy, Merino Land, Swiss BlackBrown Mountain, Swiss Charollais, Swiss White Alpine, and Valais Blacknose) were involved in this study. First colostrum samples were obtained from ewes $(\mathrm{n}=$ 100) and goats $(\mathrm{n}=116)$ between 10 and $390 \mathrm{~min}$ after parturition and analyzed for total $\mathrm{IgG}$, fat, protein, and lactose contents. Colostral IgG concentrations varied between 4.8 and $75.0 \mathrm{mg} / \mathrm{mL}$ in goats, and between 6.2 and $65.4 \mathrm{mg} / \mathrm{mL}$ in ewes, and the time interval between milking and parturition did not affect colostral IgG concentrations. In goats, the highest IgG concentrations were found in Boer (meat-type; $61.0 \pm 10.3$ $\mathrm{mg} / \mathrm{mL}$; mean $\pm \mathrm{SD})$ and the lowest concentrations were observed in Bunte Deutsche Edelziege (milk-type; $26.5 \pm 12.5 \mathrm{mg} / \mathrm{mL}$ ). In sheep, East Friesian Milk and Lacaune Dairy showed the lowest colostral IgG concentrations $(17.9 \pm 7.3$ and $20.2 \pm 8.0 \mathrm{mg} / \mathrm{mL}$, respectively), and the highest values were observed in the Merino Land breed $(44.2 \pm 15.7 \mathrm{mg} / \mathrm{mL})$. The lowest fat and protein concentrations and concomitantly highest lactose concentrations were observed in colostrum of East Friesian Milk and Lacaune Dairy sheep. Parity number did not affect colostrum composition in sheep

Received December 31, 2018.

Accepted February 4, 2019.

*Corresponding author: josef.gross@vetsuisse.unibe.ch or goats. In contrast, colostral fat content was higher in ewes bearing twins and triplets than in those carrying singletons. Increasing litter size tended to be associated with higher protein and lower lactose concentrations in ovine (i.e., singletons vs. twins vs. triplets) and caprine colostrum (i.e., singletons vs. twins), whereas colostral IgG concentrations were not affected by litter size. In conclusion, IgG and concentrations of other colostrum constituents showed a wide range in goats and ewes and were mainly affected by the type of breed.

Key words: immunoglobulin G, colostrum, sheep, goat

\section{INTRODUCTION}

In small ruminants, the placenta prevents the maternal transfer of immunoglobulins to the fetus during gestation. Thus, lambs and goat kids rely on the timely ingestion of immunoglobulin via maternal colostrum to acquire an initial passive immunity that protects them against infections during early life (Halliday and Williams, 1979; Argüello et al., 2004). If colostrum is not provided in sufficient quantity or quality within the first hours of life, the neonate is at risk of failure of passive immune transfer (FPT) leading to increased morbidity and mortality (Gilbert et al., 1988; O'Brien and Sherman, 1993). O'Brien and Sherman (1993) defined FPT in goat kids as serum IgG concentrations $<12 \mathrm{mg} / \mathrm{mL}$; in lambs, Massimini et al. (2006) noted that the optimal $\operatorname{IgG}$ serum concentration to avoid FPT was between 6 and $16 \mathrm{mg} / \mathrm{mL}$, whereas other authors used $15 \mathrm{mg} / \mathrm{mL}$ as the threshold (Hunter et al., 1977; Turquino et al., 2011; Alves et al., 2015). Hence, Morrical et al. (1995) and Bentley (2018) proposed that the quantity of colostrum that lambs and kids should ingest was $10 \%$ per kilogram of BW within $24 \mathrm{~h}$ of life (approximately $400 \mathrm{~g}$ of colostrum within $24 \mathrm{~h}$ assuming a birth weight of $4 \mathrm{~kg}$ ), whereas Mellor and Murray (1986) recommended 180 to $210 \mathrm{~mL}$ of colostrum during the first $18 \mathrm{~h}$ of life for lambs (approximately 240 to $280 \mathrm{~g}$ of colostrum within $24 \mathrm{~h}$ independent of birth weight). Consequently, colostrum quality in terms of its IgG content must be high enough to ensure a sufficient 
passive immunization. In addition, consumption of a sufficient amount of colostrum is crucial to meet the high energy demand of newborn small ruminants to support their thermoregulation. Lambs born to ewes with a higher colostral fat content were better able to maintain their body temperature during the first $24 \mathrm{~h}$ after birth (Dwyer and Morgan, 2006).

Published data on IgG concentrations and constituents in colostrum of ewes and goats revealed apparent differences between breeds. In dairy goats, average IgG concentrations measured in colostrum varied from 28.2 $\mathrm{mg} / \mathrm{mL}$ in the Murciano-Granadina breed (Romero et al., 2013) to $72 \mathrm{mg} / \mathrm{mL}$ in a Chinese strain of Saanen goats (Yang et al., 2009, whereas colostral IgG contents of the Majorera breed (Moreno-Indias et al., 2012), the Alpine goat (Levieux et al., 2002), and the Weisse Deutsche Edelziege (Rudovsky et al., 2008) were intermediate. In sheep raised for meat production, colostral IgG concentrations in Blackface (Dwyer and Morgan, 2006), Suffolk (Dwyer and Morgan, 2006), and Rasa Aragonesa ewes (Loste et al., 2008) ranged between $37 \mathrm{mg} / \mathrm{mL}$, as found in Santa Inês ewes (Alves et al., 2015), and $79 \mathrm{mg} / \mathrm{mL}$, as measured in Polypay ewes (al-Sabbagh et al., 1995). Data on IgG concentrations in colostrum of purebred dairy sheep are rare except for Awassi ewes studied by Higaki et al. (2013). Considering the constituents of colostrum, average protein concentrations in sheep colostrum of Polish Merino, Chio, and Canarian sheep varied between 14 and 22\% (Hadjipanayiotou, 1995; Ciuryk et al., 2004; Hernández-Castellano et al., 2016), and between 10 and $16 \%$ in Damascus, Majorera, and Murciano-Granadina goats (Hadjipanayiotou, 1995; Moreno-Indias et al., 2012; Romero et al., 2013). Fat and lactose contents in colostrum, however, showed less variation in the studies cited above.

However, it must be emphasized that, so far, only single individual breeds have been investigated in terms of colostrum composition. Direct breed comparisons are rarely performed and the results shown above may be affected by differences in analytical procedures and sampling protocols. Furthermore, individual animal variation of colostrum composition, as known in dairy cows (Baumrucker et al., 2010; Gross et al., 2017), needs to be considered before drawing conclusions in terms of breed differences.

In Europe, small dairy ruminants are mainly concentrated in the Mediterranean and Black Sea regions (de Rancourt et al., 2006; Pulina et al., 2018), whereas significant meat production from sheep and goats is located in the United Kingdom, Ireland, and the Mediterranean countries (EUROSTAT, 2017). After the Second World War, goat and sheep production in Switzerland and Germany declined tremendously (FAO, 2019) and these breeds are of marginal importance today. Data on colostrum composition of local and endangered breeds are scarce.

Therefore, the aim of the present study was to investigate $\operatorname{IgG}$, fat, protein, and lactose concentrations in colostrum of different goat and sheep breeds raised for milk and meat production in alpine areas in Switzerland and Germany.

\section{MATERIALS AND METHODS}

\section{Animals and Colostrum Sampling}

Colostrum samples (116 from goats and 100 from ewes) analyzed in this study were collected by goat and sheep farmers in Switzerland and Germany. Twentyeight farmers volunteered to participate in this study. All of them practice an intensive lambing/kidding management (e.g., close monitoring of parturition, frozen colostrum reserves, and strict bottle-feeding of colostrum to the neonates). In total, 10 goat and 10 sheep breeds could be enrolled (Table 1). Farmers provided approximately $50 \mathrm{~mL}$ of goat or sheep colostrum (frozen at $-20^{\circ} \mathrm{C}$ ) per animal. Farmers obtained representative colostrum samples after milking the dams for bottle-feeding of colostrum to the neonates. After bottle-feeding of colostrum, offspring were allowed to freely suckle from their mothers. Participating farmers completed a questionnaire containing information about the individual dams (e.g., parity number, litter size), time of parturition, and first milking of colostrum. Colostrum samples were taken before suckling, between 10 and 300 min after kidding in goats, and between 10 and 390 min after lambing in sheep. Two-thirds of the samples were collected within $2 \mathrm{~h}$ after parturition.

\section{IgG Determination in Goat and Sheep Colostrum}

Total IgG concentration in colostrum was measured by ELISA using a goat-specific commercial kit (catalog number E50-104; Bethyl Laboratories Inc., Montgomery, TX) according to the manufacturer's instructions for goats, and as described by Hernández-Castellano et al. $(2014,2015)$ for the use in sheep. Colostrum samples were thawed at room temperature and serially diluted 1:400,000 in ELISA wash buffer $(50 \mathrm{~m} M$ Tris, $0.14 M$ $\mathrm{NaCl}, 0.05 \%$ Tween 20, adjusted to $\mathrm{pH} 8.0$ ). The interassay coefficients of variation (CV) were $5.13 \%$ for goats and $4.69 \%$ for sheep; intra-assay CV were $6.40 \%$ for goats and $6.95 \%$ for sheep, respectively. Results were expressed as $\operatorname{IgG}$ concentration in milligrams per milliliter. 
Table 1. Goat and sheep breeds, purpose, and number of animals included in the present study

\begin{tabular}{llr}
\hline Breed & Purpose & $\mathrm{n}$ \\
\hline Goats & & 8 \\
Anglo-Nubian & Dairy and meat & 18 \\
Appenzell & Dairy & 6 \\
Boer & Meat & 10 \\
Bunte Deutsche Edelziege & Dairy & 16 \\
Chamois-colored & Dairy & 9 \\
Grisons Striped & Dairy & 6 \\
Peacock & Dairy & 18 \\
Saanen & Dairy & 21 \\
Toggenburg & Dairy & 4 \\
Valais Blackneck & Dairy and meat & 11 \\
Sheep & & 8 \\
Brown-Headed Meat & Meat & 8 \\
German Blackheaded Mutton & Meat & 9 \\
Gray Horned Heath & Landscape conservation & 17 \\
East Friesian Milk & Dairy & 12 \\
Lacaune Dairy & Dairy & 15 \\
Merino Land & Meat & 6 \\
Swiss Black-Brown Mountain & Meat & 6 \\
Swiss Charollais & Meat & 8 \\
Swiss White Alpine & Meat & Meat \\
Valais Blacknose & & \\
\hline
\end{tabular}

\section{Measurement of Goat and Sheep Colostrum Constituents}

Because of their high viscosity, sheep colostrum samples were diluted 1:2 with distilled water before measurement, whereas fat, protein, and lactose in goat colostrum samples were measured in undiluted samples. Concentrations of fat, protein, and lactose in colostrum samples were assessed by an infrared milk analyzer validated for the measurement of goat and sheep milk constituents (MilkoScan-FT, Fossomatic, Hillerød, Denmark; Suisselab AG, Zollikofen, Switzerland).

\section{Statistical Analysis}

All data are presented as mean values \pm standard deviations. Statistical analysis was performed using SAS software (version 9.4, SAS Institute Inc., Cary, NC). Data were checked for normal distribution. Dunnett's test was used to assess differences in colostral IgG, fat, protein, and lactose concentrations between goat and sheep breeds. The GLM procedure was used to analyze effects of parity number and litter size on $\operatorname{IgG}$, fat, protein, and lactose concentrations in colostrum of the individual goat and sheep breeds. Effects were considered significant at $P<0.05$.

\section{RESULTS AND DISCUSSION}

Concentrations of $\mathrm{IgG}$ and colostrum constituents are known to vary between sheep (e.g., Dwyer and Morgan,
2006; Alves et al., 2015; Hernández-Castellano et al., 2016) and goat breeds (Caja et al., 2006; Rudovsky et al., 2008; Moreno-Indias et al., 2012). However, reports investigating colostrum composition of breeds typical for Switzerland and Germany are scarce. This study aimed to fill this gap by investigating $\operatorname{IgG}$, fat, protein, and lactose concentrations in colostrum of the most common (e.g., Swiss White Alpine sheep, Chamois-colored goat) breeds and also some endangered sheep and goat breeds (e.g., Gray Horned Heath sheep, Peacock goat).

The broad range of IgG concentrations we observed over all breeds in caprine ( 4.8 to $75.0 \mathrm{mg} / \mathrm{mL}$; Figure $1 \mathrm{~A}$ ) and ovine (6.2 to $65.4 \mathrm{mg} / \mathrm{mL}$; Figure 1B) colostrum is in agreement with previous findings in Santa Inês ewes (1.2 to $60.7 \mathrm{mg} / \mathrm{mL}$; Alves et al., 2015) and Murciano-Granadina goats (23.5 to $64.0 \mathrm{mg} / \mathrm{mL}$; Caja et al., 2006). However, because of the small number of samples for some breeds, our observations and measurements might not represent the overall variation in IgG and colostral components. We further point out that this high variation in colostral IgG concentrations was not due to different time intervals between parturition and milking $(P>0.05)$ or different laboratory procedures for IgG determination. In the present study, colostrum from Boer goats exhibited, on average, the highest IgG concentrations, which were greater than most of the other examined goat breeds $(P<0.05$; Figure 1A). Boer goats are a meat-type breed, whereas the other studied goat breeds, except for the Anglo-Nubian and Valais Blackneck (dual-purpose), are raised for milk 

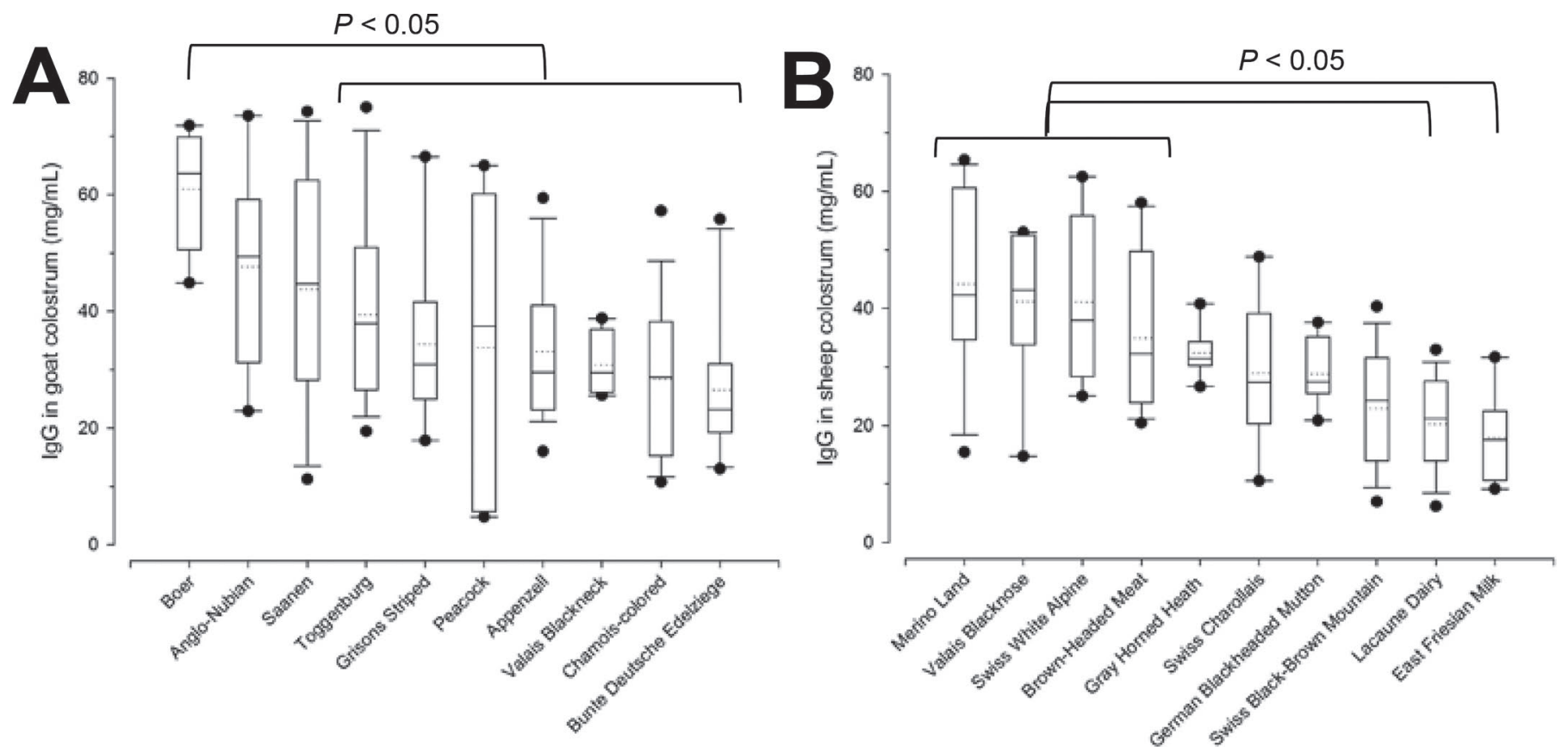

Figure 1. Immunoglobulin G concentrations $(\mathrm{mg} / \mathrm{mL})$ in colostrum of different goat (A) and sheep (B) breeds in Germany and Switzerland. The box indicates the 25th to 75th quartile, the solid line within the box represents the median, the dotted line shows the mean of the data, and the whiskers show the 10th to 90th percentile distribution of the data. The solid dots outside the whiskers indicate the 5th/95th percentiles.

production (Table 1). Similarly, we observed the lowest IgG concentrations in the colostrum of the dairy sheep breeds Lacaune Dairy and East Friesian Milk (Figure 1B). The hypothesis of higher colostral IgG concentrations in meat-type compared with milk-type breeds is supported by the studies of Guy et al. (1994) and Pattinson and Thomas (2004), which reported higher IgG concentrations in colostrum of meat-type ewes and beef cows compared with that in dairy breeds.

According to Alves et al. (2015), the consumption of at least $30 \mathrm{~g}$ of $\operatorname{IgG}$ during the first day of life should guarantee a sufficient transfer of immunoglobulins to lambs. If we apply this criterion to the Lacaune Dairy and East Friesian Milk sheep of the present study, their lambs would require at least $1.6 \mathrm{~L}$ of colostrum with our determined concentration of $18 \mathrm{mg}$ of $\mathrm{IgG} / \mathrm{mL}$ during the first $24 \mathrm{~h}$ of life. In comparison, Merino Land lambs should ingest $0.7 \mathrm{~L}$ of colostrum containing 44 $\mathrm{mg}$ of $\mathrm{IgG} / \mathrm{mL}$. The ingestion of approximately $200 \mathrm{~mL}$ of colostrum $/ \mathrm{kg}$ of BW during the first $18 \mathrm{~h}$ of life (which equates to $1.3 \mathrm{~kg}$ of colostrum/24 h of life for a 5 -kg lamb) as proposed by Mellor and Murray (1986) appears plausible to meet the IgG and energy requirements of newborn milk- and meat-type lambs.

For goats, Castro et al. (2007) showed that feeding $4 \mathrm{~g}$ of $\mathrm{IgG} / \mathrm{kg}$ of $\mathrm{BW}$ within $24 \mathrm{~h}$ provided adequate passive immunization in $80 \%$ of the kids. Applying this value to Boer and Bunte Deutsche Edelziege goats of the present study, kids should consume $0.2 \mathrm{~kg}$ of colostrum $/ 3 \mathrm{~kg}$ of BW with an IgG concentration of 60 $\mathrm{mg} / \mathrm{mL}$ and $0.5 \mathrm{~kg}$ of colostrum $/ 3.5 \mathrm{~kg}$ of BW with an IgG concentration of $27 \mathrm{mg} / \mathrm{mL}$, respectively. Consequently, the minimum colostrum supply of $10 \% / \mathrm{kg}$ of BW recommended by Bentley (2018) is adequate for goats producing colostrum with high IgG concentrations but might be critical for kids born to dams with poor colostrum quality.

In agreement with findings of Hadjipanayiotou (1995), we observed that ovine colostrum contained higher fat and protein concentrations than caprine colostrum (Table 2). In both species, colostrum constituents varied widely, with fat, protein, and lactose concentrations between 1.3 and $16.5 \%, 4.9$ and $25.1 \%$, and 2.1 and $6.0 \%$ in goats, and between 1.1 and $24.8 \%$, 7.3 and $30.5 \%$, and 1.3 and $4.6 \%$ in sheep, respectively (Table 2). In goats, differences in colostrum composition between breeds were not striking. In contrast, both dairy sheep breeds had lower fat and protein with concomitantly higher lactose concentrations in colostrum compared with most of the meat-type ewes. The increased colostral lactose concentrations could be characteristic for dairy ewes. The iso-osmolarity of milk is thereby maintained by lower concentrations of fat and protein. Unfortunately, our data do not allow conclu- 
KESSLER ET AL.

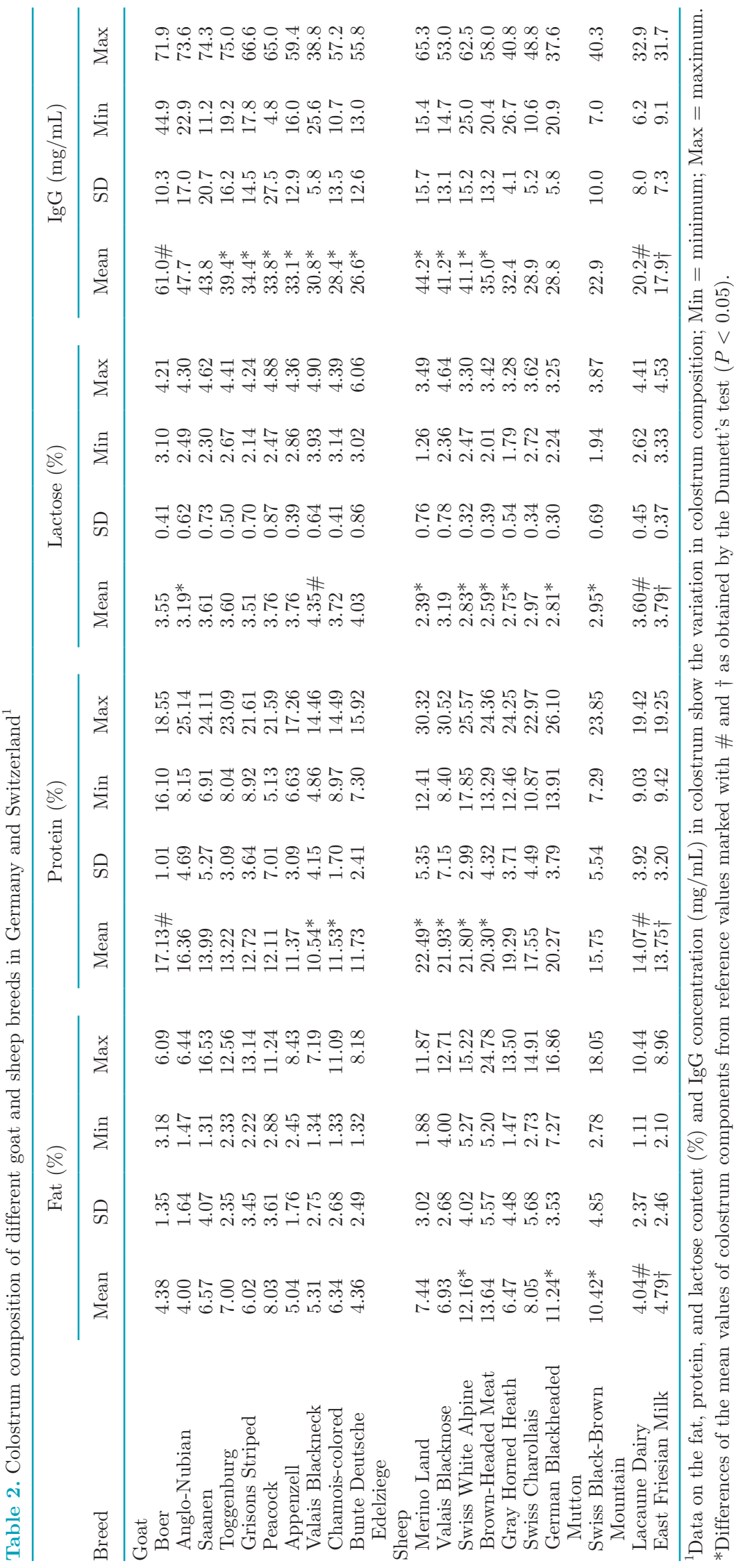


Table 3. Descriptive statistics of time between parturition and colostrum milking, distribution of parity number, litter size, and lamb/kid sex in goats and sheep

\begin{tabular}{|c|c|c|c|c|c|c|}
\hline \multirow[b]{2}{*}{ Species } & \multicolumn{6}{|c|}{ Time between parturition and colostrum milking } \\
\hline & \multicolumn{2}{|c|}{$\leq 2 \mathrm{~h}$} & \multicolumn{2}{|c|}{$2-4 \mathrm{~h}$} & \multicolumn{2}{|c|}{$>4 \mathrm{~h}$} \\
\hline \multirow{4}{*}{$\begin{array}{l}\text { Goat } \\
\text { Sheep }\end{array}$} & \multirow{2}{*}{\multicolumn{2}{|c|}{$\begin{array}{l}65 \% \\
61 \%\end{array}$}} & \multirow{2}{*}{\multicolumn{2}{|c|}{$\begin{array}{l}25 \% \\
17 \%\end{array}$}} & \multirow{2}{*}{\multicolumn{2}{|c|}{$\begin{array}{l}10 \% \\
22 \%\end{array}$}} \\
\hline & & & & & & \\
\hline & \multicolumn{6}{|c|}{ Parity } \\
\hline & \multicolumn{2}{|c|}{ Primiparous } & & & \multicolumn{2}{|c|}{ Multiparous } \\
\hline \multirow[t]{3}{*}{$\begin{array}{l}\text { Goat } \\
\text { Sheep }\end{array}$} & \multicolumn{2}{|c|}{$\begin{array}{l}24 \% \\
25 \%\end{array}$} & & & \multicolumn{2}{|c|}{$\begin{array}{l}76 \% \\
75 \%\end{array}$} \\
\hline & \multicolumn{6}{|c|}{ Litter size and kid/lamb sex } \\
\hline & \multicolumn{2}{|c|}{ Singleton } & \multicolumn{2}{|c|}{ Twin } & \multicolumn{2}{|c|}{ Triplet } \\
\hline \multirow[t]{2}{*}{$\begin{array}{l}\text { Goat } \\
\text { Sheep }\end{array}$} & \multicolumn{2}{|c|}{$\begin{array}{l}40 \% \\
27 \%\end{array}$} & \multicolumn{2}{|c|}{$\begin{array}{l}55 \% \\
55 \%\end{array}$} & \multicolumn{2}{|c|}{$\begin{array}{r}5 \% \\
18 \%\end{array}$} \\
\hline & Male & Female & Male & Female & Male & Female \\
\hline Kids & $44 \%$ & $56 \%$ & $52 \%$ & $48 \%$ & $60 \%$ & $40 \%$ \\
\hline Lambs & $25 \%$ & $75 \%$ & $48 \%$ & $52 \%$ & $51 \%$ & $49 \%$ \\
\hline
\end{tabular}

sions to be made about breed differences in colostrum production. Pattinson and Thomas (2004) observed higher colostrum production in milk-type compared with meat-type ewes.

In line with previous work (Dwyer and Morgan, 2006; Carnicella et al., 2008; Zhang et al., 2009), we observed that twins were the most common litter size in both species, whereas triplets were frequent in ewes $(17 \%)$ but rare in goats (5\%; Table 3). Gilbert et al. (1988) and Csapó et al. (1994) observed that colostral IgG concentrations increased with litter size in ewes and goats. However, in agreement with more recent literature (Argüello et al., 2006; Romero et al., 2013; Alves et al., 2015), litter size did not affect the IgG concentration in caprine and ovine colostrum in the present study $(P>0.05)$. In contrast, fat content in ovine colostrum was higher in dams with twins and triplets than in those bearing singletons $(P<0.01)$. Furthermore, colostral protein concentration tended to be higher, whereas lactose concentration tended to be lower in twin and triplet litters in sheep and in twins in goats $(P=0.07$ and 0.09 for goats, and $P=0.05$ and 0.05 for sheep, respectively). Higher protein and fat contents in colostrum, especially in ewes bearing triplets, might represent a mechanism to supply all newborns with sufficient energy to maintain their body temperature after birth, although iso-osmolarity in milk is maintained by, concomitantly, a lower concentration of lactose. Earlier studies showed that differences in placental lactogen in ruminants with greater litter size were associated with an enhanced stimulation of mammogenesis (Butler et al., 1981; Forsyth, 1986). Thus, the adjustment of mammary growth in dams bearing twins or triplets could contribute to meet the increased demands of the offspring (Byatt et al., 1992).

Results on the effect of parity number on IgG concentration in ovine colostrum are somewhat controversial. Gilbert et al. (1988) and Higaki et al. (2013) observed higher IgG concentrations in colostrum of multiparous ewes than that of primiparous ewes, whereas no effect of parity was found by Alves et al. (2015) in ewes and by several authors in goats (Argüello et al., 2006; Romero et al., 2013). In the present study, parity of the dam did not affect colostral IgG concentration in either species $(P>0.05)$. In addition, no effects of age of the dam on fat, protein, or lactose concentrations in caprine and ovine colostrum were detected $(P>0.05)$.

\section{CONCLUSIONS}

In this study of different goat and sheep breeds, colostral IgG, fat, protein, and lactose concentrations varied broadly between individual animals and breeds. Breed type (meat or dairy) of the dam affected IgG concentrations in colostrum, with meat-type goats showing the greatest and dairy sheep breeds the lowest IgG concentrations. Litter size was associated with changes in colostrum composition except IgG content. The high variation in colostral constituents and IgG concentration has clear implications for the minimum 
colostrum quantity required by lambs and kids to meet their energy demands and to obtain adequate passive immunization.

\section{ACKNOWLEDGMENTS}

We thank the participating farmers for providing the goat and sheep colostrum samples. We also thank Suisselab (Zollikofen, Switzerland) for the analysis of colostrum composition in the goat and sheep samples.

\section{REFERENCES}

al-Sabbagh, T. A., L. V. Swanson, and J. M. Thompson. 1995. The effect of ewe body condition at lambing on colostral immunoglobulin G concentration and lamb performance. J. Anim. Sci. 73:2860-2864.

Alves, A. C., N. G. Alves, I. J. Ascari, F. B. Junqueira, A. S. Coutinho, R. R. Lima, J. R. O. Pérez, S. O. De Paula, I. F. FurushoGarcia, and L. R. Abreu. 2015. Colostrum composition of Santa Inês sheep and passive transfer of immunity to lambs. J. Dairy Sci. 98:3706-3716. https://doi.org/10.3168/jds.2014-7992.

Argüello, A., N. Castro, S. Álvarez, and J. Capote. 2006. Effects of the number of lactations and litter size on chemical composition and physical characteristics of goat colostrum. Small Rumin. Res. 64:53-59. https://doi.org/10.1016/j.smallrumres.2005.03.016.

Argüello, A., N. Castro, M. J. Zamoranoa, A. Castroalonso, and J Capote. 2004. Technical note: Passive transfer of immunity in kid goats fed refrigerated and frozen goat colostrum and commercial sheep colostrum. Small Rumin. Res. 54:237-241. https://doi.org/ 10.1016/j.smallrumres.2003.11.008.

Baumrucker, C. R., A. M. Burkett, A. L. Magliaro-Macrina, and C. D. Dechow. 2010. Colostrogenesis: Mass transfer of immunoglobulin $\mathrm{G}_{1}$ into colostrum. J. Dairy Sci. 93:3031-3038. https://doi.org/10 $.3168 /$ jds.2009-2963.

Bentley, J. 2018. Colostrum management for the dairy goat kid. Fact sheet. Iowa State University, Ames. Accessed Aug. 9, 2018. https: //www.extension.iastate.edu/dairyteam/people/jennifer-bentley.

Butler, W. R., S. M. Fullenkamp, L. A. Cappiello, and S. Handwerger. 1981. The relationship between breed and litter size in sheep and maternal serum concentrations of placental lactogen, estradiol and progesterone. J. Anim. Sci. 53:1077-1081.

Byatt, J. C., W. C. Warren, P. J. Eppard, N. R. Staten, G. G. Krivi, and R. J. Collier. 1992. Ruminant placental lactogens: Structure and biology. J. Anim. Sci. 70:2911-2923.

Caja, G., A. A. K. Salama, and X. Such. 2006. Omitting the dry-off period negatively affects colostrum and milk yield in dairy goats. J. Dairy Sci. 89:4220-4228. https://doi.org/10.3168/jds.S0022 $-0302(06) 72467-5$.

Carnicella, D., M. Dario, M. C. C. Ayres, V. Laudadio, and C. Dario. 2008. Short communication: The effect of diet, parity, year and number of kids on milk yield and milk composition in Maltese goat. Small Rumin. Res. 77:71-74. https://doi.org/10.1016/j .smallrumres.2008.02.006.

Castro, N., J. Capote, L. Morales, E. Quesada, H. Briggs, and A. Argüello. 2007. Short communication: Addition of milk replacer to colostrum whey: Effect on immunoglobulin G passive transfer in Majorera kids. J. Dairy Sci. 90:2347-2349. https://doi.org/10 $.3168 /$ jds.2006-624.

Ciuryk, S., E. Molik, U. Kaczor, and G. Bonczar. 2004. Chemical composition of colostrum and milk of Polish Merino sheep lambing at different times. Arch. Anim. Breed. 47(Special Issue):129-134.

Csapó, J., Z. Csapó-Kiss, T. G. Martin, J. Szentpeteri, and G. Wolf. 1994. Composition of colostrum from goats, ewes and cows producing twins. Int. Dairy J. 4:445-458. https://doi.org/10.1016/ 0958-6946(94)90058-2. de Rancourt, M., N. Fois, M. P. Lavín, E. Tchakérian, and F. Vallerand. 2006. Mediterranean sheep and goats production: An uncertain future. Small Rumin. Res. 62:167-179. https://doi.org/10 .1016/j.smallrumres.2005.08.012.

Dwyer, C. M., and C. A. Morgan. 2006. Maintenance of body temperature in the neonatal lamb: Effects of breed, birth weight, and litter size. J. Anim. Sci. 84:1093-1101.

EUROSTAT. 2017. Statistical office of the European Union. Accessed Jul. 31, 2018. http://ec.europa.eu/eurostat/data/database.

FAO. 2019. Food and Agriculture Organization of the United Nations. Accessed Jan. 27, 2019. http://www.fao.org/faostat/en/\#data/ QA.

Forsyth, I. A. 1986. Variation among species in the endocrine control of mammary growth and function: the roles of prolactin, growth hormone, and placental lactogen. J. Dairy Sci. 69:886-903. https:/ /doi.org/10.3168/jds.S0022-0302(86)80479-9.

Gilbert, R. P., C. T. Gaskins, J. K. Hillers, C. F. Parker, and T. C. McGuire. 1988. Genetic and environmental factors affecting immunoglobulin G1 concentrations in ewe colostrum and lamb serum. J. Anim. Sci. 66:855-863.

Gross, J. J., E. C. Kessler, and R. M. Bruckmaier. 2017. Quarter vs. composite colostrum composition assessed by Brix refractometry specific gravity and visual color appearance in primiparous and multiparous dairy cows. Transl. Anim. Sci. 1:26-35. https://doi .org/10.2527/tas2016.0001.

Guy, M. A., T. B. McFadden, D. C. Cockrell, and T. E. Besser. 1994. Regulation of colostrum formation in beef and dairy cows. J. Dairy Sci. 77:3002-3007. https://doi.org/10.3168/jds.S0022 $-0302(94) 77241-6$.

Hadjipanayiotou, M. 1995. Composition of ewe, goat and cow milk and of colostrum and goats. Small Rumin. Res. 18:255-262. https://doi .org/10.1016/0921-4488(95)00697-3.

Halliday, R., and M. R. Williams. 1979. The absorption of immunoglobulin from colostrum by bottle fed lambs. Ann. Rech. Vet. 10:549-556.

Hernández-Castellano, L. E., A. Almeida, M. Ventosa, A. Coelho, N. Castro, and A. Argüello. 2014. The effect of colostrum intake on blood plasma proteome profile in newborn lambs: Low abundance proteins. BMC Vet. Res. 10:85. https://doi.org/10.1186/1746-6148 $-10-85$.

Hernández-Castellano, L. E., A. M. Almeida, J. Renaut, A. Argüello, and N. Castro. 2016. A proteomics study of colostrum and milk from the two major small ruminant dairy breeds from the Canary Islands: A bovine milk comparison perspective. J. Dairy Res. 83:366-374. https://doi.org/10.1017/S0022029916000273.

Hernández-Castellano, L. E., I. Moreno-Indias, A. Morales-delaNuez, D. Sánchez-Macías, A. Torres, J. Capote, A. Argüello, and N. Castro. 2015. The effect of milk source on body weight and immune status of lambs. Livest. Sci. 175:70-76. https://doi.org/10.1016/j .livsci.2015.02.011.

Higaki, S., M. Nagano, S. Katagiri, and Y. Takahashi. 2013. Effects of parity and litter size on the energy contents and immunoglobulin G concentrations of Awassi ewe colostrum. Turk. J. Vet. Anim. Sci. 37:109-112. https://doi.org/10.3906/vet-1111-12.

Hunter, A. G., J. K. Reneau, and J. B. Williams. 1977. Factors affecting IgG concentration in day-old lambs. J. Anim. Sci. 45:11461151

Levieux, D., F. Morgan, N. Geneix, I. Masle, and F. Bouvier. 2002. Caprine immunoglobulin G, $\beta$-lactoglobulin, $\alpha$-lactalbumin and serum albumin in colostrum and milk during the early post partum period. J. Dairy Res. 69:391-399.

Loste, A., J. J. Ramos, A. Fernández, L. M. Ferrer, D. Lacasta, M. T. Verde, M. C. Marca, and A. Ortín. 2008. Effect of colostrum treated by heat on immunological parameters in newborn lambs. Livest. Sci. 117:176-183. https://doi.org/10.1016/j.livsci.2007.12.012.

Massimini, G., A. Peli, A. Boari, and D. Britti. 2006. Evaluation of assay procedures for prediction of passive transfer status in lambs. Am. J. Vet. Res. 67:593-598. https://doi.org/10.2460/ajvr.67.4 .593 . 
Mellor, D. J., and L. Murray. 1986. Making the most of colostrum at lambing. Vet. Rec. 118:351-353.

Moreno-Indias, I., D. Sánchez-Macías, N. Castro, A. Morales-delaNuez, L. E. Hernández-Castellano, J. Capote, and A. Argüello. 2012. Chemical composition and immune status of dairy goat colostrum fractions during the first $10 \mathrm{~h}$ after partum. Small Rumin. Res. 103:220-224. https://doi.org/10.1016/j.smallrumres.2011.09.015.

Morrical, D., N. R. Hartwig, and C. Youngs. 1995. Colostrum and health of newborn lambs. Sheep Management. Fact sheet 12. Iowa State University, Ames.

O'Brien, J. P., and D. M. Sherman. 1993. Serum immunoglobulin concentrations of newborn goat kids and subsequent kid survival through weaning. Small Rumin. Res. 11:71-77.

Pattinson, S. E., and E. W. Thomas. 2004. The effect of sire breed on colostrum production of crossbred ewes. Livest. Prod. Sci. 86:4753. https://doi.org/10.1016/S0301-6226(03)00169-6.

Pulina, G., M. J. Milán, M. P. Lavín, A. Theodoridis, E. Morin, J. Capote, D. L. Thomas, A. H. D. Francesconi, and G. Caja. 2018. Invited review: Current production trends, farm structures, and economics of the dairy sheep and goat sectors. J. Dairy Sci. 101:6715-6729. https://doi.org/10.3168/jds.2017-14015.
Romero, T., M. C. Beltrán, M. Rodríguez, A. Martí De Olives, and M. P. Molina. 2013. Short communication: Goat colostrum quality: Litter size and lactation number effects. J. Dairy Sci. 96:75267531. https://doi.org/10.3168/jds.2013-6900.

Rudovsky, A., L. Locher, A. Zeyner, A. Sobiraj, and T. Wittek. 2008. Measurement of immunoglobulin concentration in goat colostrum. Small Rumin. Res. 74:265-269. https://doi.org/10.1016/j .smallrumres.2007.06.003.

Turquino, C. F., K. M. C. Flaiban, and J. A. N. Lisbôa. 2011. Transferência de imunidade passiva em cordeiros de corte manejados extensivamente em clima tropical. Pesqui. Vet. Bras. 31:199-205.

Yang, X.-Y., J.-P. Chen, and F.-X. Zhang. 2009. Research on the chemical composition of Saanen goat colostrum. Int. J. Dairy Technol. 62:500-504. https://doi.org/10.1111/j.1471-0307.2009 .00515.x.

Zhang, C.-Y., Y. Zhang, D.-Q. Xu, X. Li, J. Su, and L.-G. Yang. 2009 Genetic and phenotypic parameter estimates for growth traits in Boer goat. Livest. Sci. 124:66-71. https://doi.org/10.1016/j.livsci .2008.12.010. 